\title{
Radiofrequency ablation: a review of current knowledge, therapeutic perspectives, complications, and contraindications
}

\begin{abstract}
Ablation is the thermal or chemical therapy applied directly to the tissue to cause heat induced cell death. The most popular ablative procedure is radiofrequency which is used to treat certain types of benign neoplasms. Radiofrequency ablation consists of heating the tumor by exposing it to a varying electric field applied using electrodes. The electric field causes the oscillation of free charges and ions through the tissue, producing currents and consequently resistive heating. The radiofrequency ablation uses needle-type electrodes that are introduced directly into liver tumors through laparotomy, laparoscopy, or radiologically guided percutaneously.
\end{abstract}

Keywords: ablation, radiofrequency, tumor treatment, head injury, RFA
Volume 4 Issue 2 - 2018

\author{
Mauricio Sánchez Barajas, ${ }^{1,2}$ Teodoro \\ Córdova Fraga, ${ }^{2}$ Marco A Escobar Acevedo, ${ }^{3}$ \\ Rafael Guzmán Cabrera ${ }^{4}$ \\ IInstituto Mexicano del seguro Social, México \\ ${ }^{2}$ Departamento de Ingeniería Física-DCl, Universidad de \\ Guanajuato campus León, México \\ ${ }^{3}$ Universidad De La Salle Bajío, México \\ ${ }^{4}$ Departamento de Ingeniería Eléctrica-DICIS, Universidad de \\ Guanajuato campus Irapuato-Salamanca, México
}

\begin{abstract}
Correspondence: Rafael Guzmán Cabrera, Departamento de Ingeniería Eléctrica-DICIS, Universidad de Guanajuato campus Irapuato-Salamanca, km 3.5 Carr. Salamanca-Valle de Santiago+1.8 Comunidad de Pablo Blanco, GTO, Mexico, Email guzmanc8I@gmail.com
\end{abstract}

Received: January 29, 2018 | Published: March 23, 2018

\section{Introduction}

There are numerous techniques developed throughout history to achieve tissue ablation. ${ }^{1}$ Techniques used to produce cancer cell destruction include heat, cold, radiation, chemotherapy, injection of substances to block the blood supply to the tumors, injection of intratumoral caustic agents, and the combination of several of these techniques. Most of these methods have been introduced and developed at the end of the 20th century, but there are some dating back to the 19th century, ${ }^{2}$ but percutaneous radiofrequency (RF) methods are relatively new. ${ }^{3}$ There are two types of ablation depending on their mechanism of action:

I. Chemical ablation: ethanol, acetic acid, hypertonic saline solution.

II. Thermal ablation: radiofrequency, cryoablation, microwave, laser and ultrasound. ${ }^{4}$

The radiofrequency ablation (RFA) is the most extensively studied and widely applied minimally invasive thermal ablative technique in clinical practices. The RFA is a localized heat treatment technique designed to produce tumor destruction at temperatures exceeding 50
${ }^{\circ} \mathrm{C}$. Ionic vibration by friction causes an increase in the temperature in the tissues surrounding the electrode and causes cell death due to coagulation necrosis. ${ }^{5}$ The needle's axis does not produce heat, the heat is produced in the tissue around, and this leads to coagulation and subsequently to tissue necrosis. The application of RF currents over a small area of coagulation causes carbonization of the tissue. This carbonization phenomenon acts as an inhibitor of ionic agitation in other areas thus limiting the coagulative necrosis to the region around the needle. In the last 10-15 years, there has been a rapid advance in the use of RF for the treatment of different types of tumors. ${ }^{6-8}$ Powerful energy generators have been developed, the puncture needles have been redesigned to obtain a larger area of necrosis. Different methods have been implemented to avoid heat dissipation during RF, such as large vessel embolization or temporal occlusion. ${ }^{9}$ There is ongoing research to develop technology that allows the application or RF ablation to a broader range of illnesses though out the body.

\section{Results}

In the Table 1 shown the results of therapeutic perspective, complications, contraindications.

Table I Shown the results of therapeutic perspective, complications and contraindications

\begin{tabular}{|c|c|c|}
\hline Therapeutic perspective & Complication & Contraindications \\
\hline $\begin{array}{l}\text { Effective treatment for hepatocellular } \\
\text { carcinoma and colorectal metastases } \\
\text { to the liver, treatment of tumors in the } \\
\text { lungs, brain, kidney, prostate, and bone } \\
\text { low treatment cost as compared to } \\
\text { other techniques. }\end{array}$ & $\begin{array}{l}\text { To cause necrosis injury in vascular } \\
\text { structures, cutaneous necrosis, which adds } \\
\text { to the potential risks such as infections, } \\
\text { pain, bleeding, post-blunting syndrome and } \\
\text { Ventricular Tachycardia }\end{array}$ & $\begin{array}{l}\text { RFA is considered for peripheral lesions less than } 5 \mathrm{~cm} \text { or } \\
\text { up to three lesions with diameters smaller than } 3 \mathrm{~cm} \text { in } A \text { or } \\
\text { B Child-Pough patients, with no option surgical treatment, } \\
\text { or in those patients who are poor candidates to surgical } \\
\text { procedures due to multiple comorbidities }\end{array}$ \\
\hline
\end{tabular}




\section{Discussion}

Radiofrequency ablation (RFA) can be considered in lieu of surgical management, as the first option, as the first. During RFA, an electrode is inserted percutaneously inside the tumorous tissue with the help of image guidance technique, through which the high-frequency alternating current $(450-550 \mathrm{kHz})$ is delivered into the tissue inducing frictional heating. This frictional heating leads to destruction of tumor cell by instantaneous induction of protein coagulation that irreversibly damages key cytosolic and mitochondrial enzymes and nucleic acid histone complexes at temperatures above $50^{\circ} \mathrm{C} .{ }^{10}$ Temperatures higher than $100^{\circ} \mathrm{C}$ should be avoided to prevent tissue carbonization and water vaporization that increases the tissue impedance thereby limiting further electrical conduction through the rest of the tissue. ${ }^{11}$

\section{Therapeutic perspectives}

Earlier studies have demonstrated that, RFA is not only an effective treatment for hepatocellular carcinoma and colorectal metastases to the liver, but it also of interest in the treatment of tumors in the lungs, brain, kidney, prostate, and bone. ${ }^{12-15}$ Most importantly, RFA is faster, and exhibits relatively fewer complications with improved cosmesis and low treatment cost as compared to other techniques. RFA is a minimally invasive process that consists of creating blocking lines of cardiac impulse conduction to thermally destroy ventricular tissue causing cardiac arrhythmia. ${ }^{16}$ RFA of the cavotricuspid isthmus is very effective and widespread, with a success rate above $85 \% .{ }^{17}$ The RFA as a treatment for renal cancer was introduced in 1997 by Zlotta. ${ }^{18}$ The energy is applied under temperature or impedance monitoring. The energy emitted by this technique results in ionic agitation in the tissues surrounding the site of application of the RF probe. This generates heat up to $49{ }^{\circ} \mathrm{C}$ which is responsible for cell death due to protein denaturation, direct damage to the membrane and thermal destruction of the cytoplasm. ${ }^{19}$

Other review the practice of RF ablation of lower limb varicose veins. They present the clinical evidence and best practice techniques for currently available devices, best practice techniques and evidence. ${ }^{20}$ RFA is a well-established technique to ablate dysplastic and neoplastic tissue via local thermal coagulative necrosis. Despite the widespread use in management of several cancers, the application of RFA in pancreas has been limited due to the increased risks of complications from the increased sensitivity of pancreatic tissue to thermal injury and proximity to vascular and biliary structures. RFA has been successfully used during laparotomy for locally advanced pancreatic carcinoma but requires an invasive approach. ${ }^{21}$ RFA treatment of the tongue base can be used either alone or as part of a multilevel approach in the treatment of snoring. ${ }^{22}$ RFA ablation is an alternative for patients with high surgical risk, for small lesions (less than $3 \mathrm{~cm}$ ) and preferable peripherical. Radiofrequency ablation is a therapeutic modality that emerged for the first time a decade ago as an experimental intervention. It has now proved to be a reproducible and safe therapeutic option. Depending on the type of tissue to be treated in radiofrequency ablation, the patient is placed in a dorsal or ventral position and asepsis and antisepsis are performed in the region. Local anesthetic and intravenous sedation, then the LeVeen radiofrequency needle is inserted through a tomography guide. The largest diameter of the tumor is located and the needle is directed towards the inner edge of the lesion. Once in this site the impact is realized, that can be variable depending on the characteristics and adjacent structures.
Without leaving the initial site, a second impact is made 30 seconds later, but, this time, at half the maximum temperature of the first impact. In all cases the homeostasis was verified and the patients were moved to the recovery area. ${ }^{13}$

\section{Complications}

The most feared complication of RFA is to cause necrosis injury in vascular structures, cutaneous necrosis, ${ }^{23}$ which adds to the potential risks such as infections, pain, bleeding and post-blunting syndrome. Complications that may occur in Ventricular Tachycardia ARF include lesions related to vascular access, thromboembolic events (ACV, AIT, etc.), air embolism, cardiac tamponade, valvular lesions, conduction system injuries, coronary lesions, insufficiency Cardiac. ${ }^{24}$

\section{Contraindications}

In general, radiofrequency ablation is considered for peripheral lesions less than $5 \mathrm{~cm}$ or up to three lesions with diameters smaller than $3 \mathrm{~cm}$ in A or B Child-Pough patients, with no option surgical treatment, or in those patients who are poor candidates to surgical procedures due to multiple comorbidities. Hepatocarcinoma patients, when the waiting list time for translplant is longer than six months, for local control of the tumor. Patients with good Child-Pough a functional liver reserve, and tumors less than $2 \mathrm{~cm}$, as an alternative to transplantation or surgical resection. Local recurrence of hepatic cirrhosis, after partial hepatectomy. ${ }^{25}$

\section{Conclusion}

Radiofrequency has been widely used in various chronic pain syndromes in recent years. Radiofrequency ablation is a form of electrosurgery in which a high frequency alternating current (greater than $10 \mathrm{kHz}$ ) passes from an electrode to the tissue being treated, thus releasing a huge energy in the form of heat in a very concentrated form. A radiofrequency generator is in charge of forming an electric current that through an electrode reaches the patient, returning through ground to the generator. The resistance of biological structures causes the vibration of the nearest ions. The agitation of these ions becomes friction around the electrode, as these ions attempt to produce changes in the direction of the alternating current to the point of dehydration.

\section{Acknowledgements}

None.

\section{Conflict of interest}

The author has no conflicts of interest to declare.

\section{References}

1. Feng B, Liang P. Local thermal ablation of renal cell carcinoma. Eur $J$ Radiol. 2012;81(3):437-440.

2. Van Sonnenberg E, Mc Mullen W, Solbiati L. Tumor Ablation. Principles and practice, Springer; 2005.

3. Chu KF, Dupuy DE. Thermal ablation of tumours: biological mechanisms and advances in therapy. Nat Rev Cancer. 2014;14(3):199-208.

4. Viramontes Trejo G. Indicaciones y experiencia en crioablación. Anales de Radiología México. 2011;3:140-145.

5. Iannitti DA, Dupuy DE, Mayo-Smith WW, et al. Hepatic radiofrequency ablation. Arch Surg. 2002;137(4):422-427. 
6. Chan AA, Ahrar K, Matin SF. Ablative therapies in renal cell carcinoma. Minerva Urol Nefrol. 2011;63(3):237-250.

7. Salagierski M, Akdogan B, Brookman-May S, et al. What is the contemporary role of radiofrequency ablation in the management of small renal masses? Are small lesions the radiologist's tumors? Eur Urol. 2013;63(3):493-495.

8. Zagoria RJ, Childs DD. Update on thermal ablation of renal cell carcinoma: oncologic control, technique comparison, renal function preservation, and new modalities. Curr Urol Rep. 2012;13(1):63-69.

9. Crow P, Keeley FX. Prevention and handling of complications of renal focal therapies. Journal of endourology. 2010;24(5):765-767.

10. Miller MW, Ziskin MC. Biological consequences of hyperthermia. Ultrasound Med Biol. 1989;15(8):707-722.

11. Singh S, Repaka R. Temperature-controlled radiofrequency ablation of different tissues using two-compartment models. Int $J$ Hyperthermia. 2016;30:1-13.

12. Shah DR, Green S, Elliot A, et al. Current oncologic applications of radiofrequency ablation therapies. World $J$ Gastrointest Oncol. 2013;5(4):71-80.

13. Mirza AN, Fornage BC, Sneige N. Radiofrequency ablation of solid tumors. Cancer J. 2001;7(2):95-102.

14. Fornage BD, Sneige N, Ross MI, et al. Small $(\leq 2-\mathrm{cm})$ breast cancer treated with US-guided radiofrequency ablation: feasibility study. Radiology. 2004;231(1):215-224.

15. Zhu JC, Yan TD, Morris DL. A systematic review of radio-frequency ablation for lung tumors. Ann Surg Oncol. 2008;15(6):1765-74.

16. González-Suárez A, Trujillo M, Berjano E. Estudio de la eliminación de arritmias cardíacas mediante el uso de la modelización matemática. Modelling in Sciense Education and Learning. 2013;6(2):33-40.

17. Peña Peña G, Hernández Madrid A, González Rebollo J, et al. Ablation of the cavotricuspid isthmus. Randomized prospective study of radiofrequency ablation with irrigated catheters versus standard catheters. Rev Esp Cardiol. 2002;55(1):37-44.

18. Zlotta AR, Wildschutz T, Raviv G, et al. Radiofrequency interstitial tumor ablations (RITA) a possible new modalitiy for treatment of renal cancer: ex vivo and in vivo experience. J Endourol. 1997;11(4):251-258.

19. Häcker A, Vallo S, Weiss C, et al. Minimally invasive treatment of renal cell carcinoma: comparison of 4 different monopolar radiofrequency devices. Eur Urol. 2005;48(4):584-592.

20. Goodyear SJ, Nyamekye IK. Radiofrequency ablation of varicose veins: Best practice techniques and evidence. Phlebology. 2015;30(2 Suppl):9-17.

21. Rustagi T, Chhoda A. Endoscopic Radiofrequency Ablation of the Pancreas. Dig Dis Sci. 2017;62(4):843-850.

22. Tornari C, Wong G, Arora A, et al. A unique complication of radiofrequency therapy to the tongue base. Int $J$ Surg Case Rep. 2015;8C:9-12.

23. Matin SF, Ahrar K. Nephron-sparing probe ablative therapy: long-term outcomes. Curr Opin Urol. 2008;18(2):150-156.

24. Labadet C, Dubner S, Hadid C, et al. Efficacy and Safety of Radiofrequency Catheter Ablation in Patients with Atrial Fibrillation. Rev Argen Cardiol. 2014;82:285-291.

25. Pérez MJ, Beltrán. Interventional treatment. Rev Col Gastroenterol. 2013;28(3):21-27. 